\title{
Trombektomi i cerebral vene
}
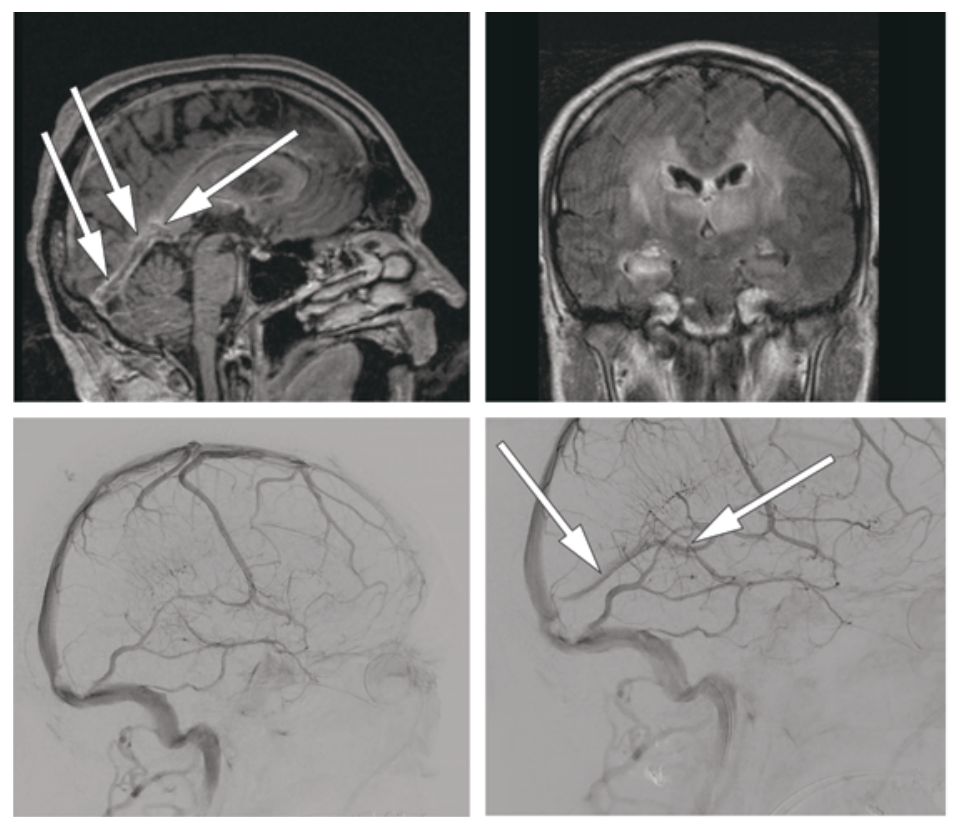

En mann i 50-årsalderen var blitt stoppet av politiet fordi han hadde kjørt bil mot kjøreretningen. Han ble innlagt med spørsmål om hjerneslag.

Ved undersøkelsen var han konfus. Cerebral CT og CT-angiografi viste åpne arterier ved primærgranskning, og tilstanden ble oppfattet som encefalitt. Dagen etter utviklet han afasi og fallende bevissthet. Det var inverterte plantarreflekser bilateralt.

På cerebral kontrastforsterket og T1-vektet MR-bilde (øverst til venstre) vises kontrastutsparing i midtlinjen $\mathrm{i}$ v. cerebri magna (v. Galeni) og sinus rectus (piler). Øverst til høyre ses bilaterale signalforandringer på FLAIR, som følge av cerebral venetrombose.

Det ble utført endovaskulær behandling på vital indikasjon. Man fikk tilgang til det intrakraniale venesystem via et kateter fra høyre v. femoralis til høyre v. jugularis interna. Et mikrokateter ble ført gjennom sinus transversus og sigmoideus til sinus rectus og v. Galeni. Etter trombeaspirasjon og trombektomi med Solitaire temporær stent var sinus rectus og v. Galeni rekanalisert. Nederst til venstre vises cerebral angiografi i venefase (sidebilde) etter kontrastinjeksjon i venstre a. carotis interna før trombektomien og nederst til høyre etterpå. Pilene markerer åpne ovennevnte venestrukturer etter behandling.

Pasienten fikk antikoagulasjonsbehandling med dalteparin i tre uker, deretter rivaroksaban. Ved utskrivning var han preget av nedsatt psykomotorisk tempo og noe redusert hukommelse, ellers var det ingen nevrologiske sekveler.

Endovaskulær trombolytisk behandling og trombektomi av venøse cerebrale kar kan være aktuelt hos pasienter med manglende klinisk respons på antikoagulasjonsbehandling (førstelinjebehandling) og rask nevrologisk forverring med bevissthetsreduksjon (1). Foreløpig foreligger det ingen data fra randomiserte kliniske studier som dokumenterer nytteverdien av mekanisk trombektomi versus antikoagulasjonsbehandling ved cerebral venetrombose (2). Effekten på mortalitet og funksjonsnivå er omdiskutert (3), og prosedyren bør foreløpig gjøres innen en registerstudie eller som ledd i en randomisert, kontrollert studie.

Pasienten har gitt samtykke til at artikkelen blir publisert.

\section{Mirza Jusufovic}

mirza.jusufovic@medisin.uio.no

Nevrologisk avdeling

Klinikk for kirurgi og nevrofag

\section{Øivind Gjertsen}

Avdeling for radiologi og nukleærmedisin/ nevroradiologisk enhet

Klinikk for diagnostikk og intervensjon

\section{Fakhira Khalid}

Nevrologisk avdeling

Klinikk for kirurgi og nevrofag

\section{Bjørn Tennøe}

Avdeling for radiologi og nukleærmedisin/ nevroradiologisk enhet

Klinikk for diagnostikk og intervensjon

\section{Mona Skjelland}

Nevrologisk avdeling

Klinikk for kirurgi og nevrofag

Oslo universitetssykehus, Rikshospitalet

Mirza Jusufovic (f. 1980) er lege i spesialisering og doktorgradsstipendiat.

Forfatter har fylt ut ICMJE-skjemaet og oppgir ingen interessekonflikter.
Øivind Gjertsen (f. 1966) er spesialist i radiologi og overlege.

Forfatter har fylt ut ICMJE-skjemaet og oppgir ingen interessekonflikter.

Fakhira Khalid (f.1980) er lege i spesialisering Forfatter har fylt ut ICMJE-skjemaet og oppgir ingen interessekonflikter.

Bjørn Tennøe (f. 1960) er spesialist i radiologi og overlege.

Forfatter har fylt ut ICMJE-skjemaet og oppgir ingen interessekonflikter.

Mona Skjelland (f. 1956) er spesialist i nevrologi og overlege.

Forfatter har fylt ut ICMJE-skjemaet og oppgir ingen interessekonflikter.

\section{Litteratur}

1. Einhäupl K, Stam J, Bousser MG et al. EFNS guideline on the treatment of cerebral venous and sinus thrombosis in adult patients. Eur J Neurol 2010: 17: 1229-35

2. Canhão P, Falcão F, Ferro JM. Thrombolytics for cerebral sinus thrombosis: a systematic review. Cerebrovasc Dis 2003; 15: 159-66.

3. Stam J, Majoie CB, van Delden OM et al. Endovas cular thrombectomy and thrombolysis for severe cerebral sinus thrombosis: a prospective study. Stroke 2008; 39: 1487-90.

Mottatt 11.5. 2015, første revisjon innsendt 24.5. 2015, godkjent 29.6. 2015. Redaktør: Inge Rasmus Groote. 